\title{
IAMJ
}

INTERNATIONAL

AYURVEDIC

MEDICAL JOURNAL

ISSN: 2320-5091

Impact Factor: 6.719

\section{PHARMACOGNOSTICAL AND PHYTOCHEMICAL RESEARCH STUDY OF ROOT PART OF BAL (TENDER) AND VRIDDHA (BOLT) MOOLAK (Raphanus Sativus Linn.)}

\author{
Rajani Patel ${ }^{1}$, Om Prakash Rout ${ }^{2}$, Pravin Kumar Joshi ${ }^{3}$ \\ ${ }^{1}$ P.G. Scholar, Department of Dravyaguna, S.N.P.A. Govt. Ayurvedic College, Raipur, Chhattisgarh, India \\ ${ }^{2}$ Department of Dravyaguna, S.N.P.A. Govt. Ayurvedic College, Raipur, Chhattisgarh, India \\ ${ }^{3}$ Professor \& H.O.D., Department of Dravyaguna, S.N.P.A. Govt. Ayurvedic College, Raipur, Chhattisgarh, India
}

Corresponding Author: rajanidobkp@gmail.com

\section{https://doi.org/10.46607/iamj03p5042021}

(Published online: May 2021)

Open Access

(C) International Ayurvedic Medical Journal, India 2021

Article Received: 19/04/2021 - Peer Reviewed: 06/05/2021 - Accepted for Publication: 07/05/2021

Check for updates

\begin{abstract}
Ayurveda treatment faces negligible complication and positive health impact on the patients, even in Ayurveda usage of herbal medicine has its own significant advantage. According to ancient science there is nothing on this earth which is not medicine. Ayurveda considers all substances as medicine, if used for specific purpose in an appropriate way. Acharyas has also described about different season, Stages and Area for collection of different part of medicinal plant. Susrut has mentioned the collection method of Ahar dravyas Samgraha in Annapanavidhi - Adhyaya where mature root is said ideal for collection, Bal (Tender) and Vriddha (bolt) root should be avoided but in special case of moolak (Radish) root, properties of Bal and Vriddha moolak are mentioned separately and in some case of disease where moolak is used as medicine especially Balmoolak is taken. Aims \& Objectives - The motive of this research is to compare both stages of moolak on the basis of literature review, pharmacognostical and phytochemical properties which further evaluates their pharmacological properties and also this study would serve as a useful gauge in isolation of medicinally important phytoconstituents, performing pharmacological investigation and ensuring quality formulations and standardization of the plant material. Materials \& Methods - TLC plate spot, Quanitative analysis of phenolic contents and flavonoids. Result - All the laboratory experiments show clear
\end{abstract}


difference between both the stages of moolak and presence of saponin defines hepatoprotective property of Balmoolak. Conclusion - The research study has shown that Balmoolak is good for GIT and biliary system but the properties of vriddha moolak are not suitable for GIT so it is called Tridoshakarak and balmoolak is called tridoshamak property.

Keywords - Bal, Vriddha, Moolak, Ahardravya.

\section{INTRODUCTION}

Moolak (Radish) is botanically Raphanus sativus Linn.of family brassicaceae (Cruciferae). It is used in different diseases as pathya and in the form of many formulations in ayurvedic literatures. All the herbal drugs are used in their mature stage. According to Bhavaprakash (Aamradiphalavarga, Shlok No. 59-60) ${ }^{2}$ the ripe fruit is preferred due to their matured qualities except in case of Bilva (Bael - Aegle marmelos) where, immature Bilva fruit is ideally taken. In case of Trapusha (Cucumber - Cucumis sativus) and Naarikela (Coconut - Cocos nucifera Linn.) also the rule is deviated where immature fruits are ideal due to their beneficiary actions and properties.

Same as Mature root is ideal but in special case of Moolak (Radish), Bal-moolak is usually used due to its good qualities and Vriddha is also mentioned in some rare places. According to Su. Su. 46/ 313 all kinds of Kandas (Tuber) which are young, unseasonal, very old, diseased, eaten by worms and insects and which do not grow well should not be used. Plant kingdom (Sthavar) is devided in four classes - Vanaspati (Flowers are not claerly seen), Vanaspatya (Flowers and Fruits are clearly seen), Virudha (Vine and Shrubs) and Osadhi. Moolak is considered in Osadhi because "Ausadha Phalapakanta"1 means those which perish after their fruits ripen.

According to modern agriculture science the harvesting age of Raphanus sativus Linn. is 30-50 days which depends upon their varieties and if not harvested at time it started to become bolt ${ }^{3}$. "Once a plant starts to bolt, its entire energy reserve is focused on producing the seed (s) and the rest of plant becomes tough, woody, tasteless and even bitter". Bolting is the production of flowering stem on agriculture and horticulture crop before the crop is harvested in a natural attempt to produce seeds but in late bolting stage root of moolak becomes hollow and degeneration also takes place which is unedible but because many literatures mentioned about the properties of Vriddha moolak, we considered early bolting stage as Vriddha moolak ${ }^{4}$. Plant such as radish and spinach hot dry weather and water stress can speed the bolting time because bolting is a survival mechanism in a plant which try to produce the next generation as quickly as possible in this tough time.

\section{Aim \& Objectives}

1. Pharmacognostical comparative analysis of $\mathrm{Bal}$ moolak and Vriddha moolak (Raphanus sativus).

2. Comparative phytochemical properties of $\mathrm{Bal}$ moolak and Vriddha moolak (Raphanus sativus).

\section{Materials and Methods}

\section{Collection of plant material:}

Here two stages of Raphanus sativus Linn. are taken for the experimental study from Raipur, Chhattisgarh which latitude is $21.25 \mathrm{~N}$ and longitude is $81.63 \mathrm{E}$.

Balmoolak ( $1^{\text {st }}$ sample) is taken just before harvesting time (approximately 6 weeks or one and half month) in December after sowing and Vriddha $\left(2^{\text {nd }}\right.$ sample) one is taken after flowering stalk appeared till fruiting stage (season: January-February). Fruit maturing stage and ripen seed stage was not taken because after that degeneration process started in roots.

Authentication of plant: Authentication of collected plant material was done in the Raw Material Herbarium \& Museum, Delhi (RHMD), National Institute of Science Communication and Information Resources (CSIR-NISCAIR).

Processing of the plant material: The collected plant materials (Roots) were separated with extraneous matter then cleaned with distilled water. They were shade dried at room temperature until they were free from moisture. Completely dried plant materials were 
pulverized in a mechanical grinder. The coarse powdered sample was stored in airtight container for further use.

\section{Pharmacognostical study:}

Organoleptic study, macroscopic study of both the sample was done.

\section{Phytochemical analysis ${ }^{6}$}

Physicochemical analysis:

Foreign matter, Determination of LOD Loss on drying), Determination of Total Ash Value, Determination of Acid insoluble Ash, Determination of Water Soluble Ash, Determination of Water Soluble Extractive (WSE) value, Alcohol Soluble Extractive (ASE) value, $\mathrm{pH}$ Value, Fluorescence analysis ${ }^{55}$, Qualitative analysis of phytochemical.

\section{Qualitative analysis of phytochemical:}

Test for Reducing Sugar (Benedicts test), Glycoside (Molisch's Test, Conc. $\mathrm{H}_{2} \mathrm{SO}_{4}$ Test), amino acid and Proteins (Ninhydrin Test, Millon's test), Steroid (Salkowski test), Flavonoids/Tannins: $\mathrm{FeCl}_{3}$ test, Lead acetate test, Alkaline Reagent test, Alkaloids: Dragendroff's test, Mayer's reagent, Saponins, Fats and Fixed oils (Stain Test), Saponification test.

Quantitative analysis for total phenolics and flavonoids:

\section{Determination of total phenols:}

Total phenols content of plant was determined by with the Folin-Ciocalteu colorimetric method, Gallic acid was used as standard.

Sample and standard absorbance was measured at 760 nm with a Shimadzu UV-1800 soectrophotometer.
Caliberation curve using ABSORBANCE vs CONCENTRATION of Gallic acid standard was prepared and the concentration of total flavonoid in the sample was determined by using a slope equation that was obtained from the standard graph and results for total phenols was expressed as $\mathrm{mg}$ of Gallic acid equivalent /g dried extract.

\section{Determination of total flavonoids:}

Total flavonoid content of plant was determined by Aluminium chloride colorimetric method, quercetin was used as standard.

Sample and standard absorbance was measured at 420 nm with a Shimardzu UV- 1800 spectrophometer. Calibration curve using ABSORBANCE vs CONCENTRATION of quercetin standard was prepared and the concentration of total flavonoid in the sample was determined by using a slope equation that was obtained from the standard graph and results for total flavonoids was expressed as $\mathrm{mg}$ of quercetin equivalent/g dried extract.

Tlc (Thin Layer Chromatography):

- Extract: Alcoholic extract of powdered drug sample.

- Stationary Phase: Aluminium sheet Silica gel $F_{254}$ (Merck KGaA company)

- Mobile Phase: Toluene: Ethyl acetate (7.5: 2.5)

- Derivatization: Vaniline + Sulphuric acid

- Visualization: TLC plate is observed under Normal light, UV-254 and UV- 366.

- $\mathrm{R}_{\mathrm{f}}$ Value Calculation

\section{RESULTS AND DISCUSSION}

Table 1: Pharmacogenetical study

Organoleptic characters of Root of Moolak (Raphanus sativus Linn.)

\begin{tabular}{|l|l|l|l|}
\hline S.N. & Character & Bal-moolak & Vriddha-moolak \\
\hline 1. & Fracture $($ Shabda) & - & - \\
\hline 2. & Taste $($ Rasa $)$ & Pungent (More than Vriddha) & Pungent \\
\hline 3. & Appearance $($ Rupa $)$ & White & Greyish white \\
\hline 4. & Smell $($ Gandha) & Unpleasant & Unpleasant \\
\hline 5. & Texture $($ Sparsha $)$ & Smooth & Rough \\
\hline
\end{tabular}


T.S. section of Balmoolak is dense, white and smooth but the T.S. of Vriddha-moolak shows more fibrous, rough and after some more time air torned fibres of bolt radish.

$>$ Organoleptic characters can be correlated with Ayurvedic Paanch-gyanendriya Pareeksha Shabda, Sparsh, Rupa, Rasa and gandha of crude drug because Organoleptic refers to evaluation by means of the organ of sense and includes the macroscopic appearance of the drug, it's odor and taste, occasionaly the sound or snap of its fracture and feel of the drug to touch.

Figure 1: Macroscopic characters of root of moolak (raphanus sativus)

(A)

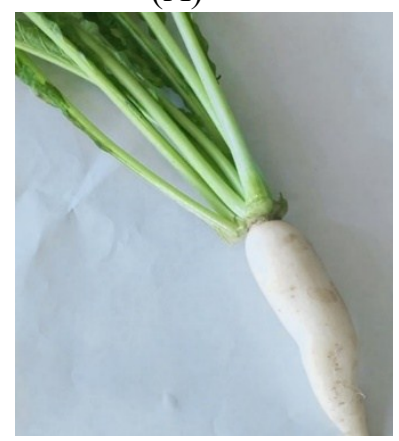

(B)

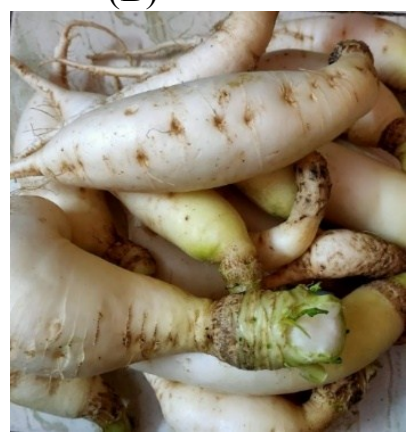

Table 2: (A) Surface of Balmoolak, (B) Surface of Vriddha moolak

\begin{tabular}{|l|l|l|l|}
\hline S.N. & Character & Bal-moolak & Vriddha-moolak \\
\hline 1. & Occurrence & White & Greyish white \\
\hline 2. & Shape & Fusiform, Cylindrical & Irregular in shape \\
\hline 3. & Surface & Smooth & Rough \\
\hline
\end{tabular}

$>$ Bright white color, fixed shape, smooth outer smooth surface and inner dense transverse section indicate its similarity to kapha but due to teekshna (Sharp) guna it doesn't alleviate Kapha more than its limit.
Greyish white, irregular shape, rough outer surface and some spongy textured transverse section indicate its similarity to vata and teekshna (Sharp) guna aggravate vata in excessively.

Table 3: Physicochemical parameter

\begin{tabular}{|l|l|l|l|}
\hline S.N. & Physicochemical parameter & Observed value & \\
\cline { 3 - 4 } & & Balmoolak & Vriddhamoolak \\
\hline 1. & Foreign matter & Nil & Nil \\
\hline 2. & Total Ash (\%) & 10.73 & 10.66 \\
\hline 3. & Acid insoluble ash (\%) & 2.36 & 2.9 \\
\hline 4. & Alcohol soluble extractive value & $15.02 \%$ & $15.224 \%$ \\
\hline 5. & Water soluble extractive value & $32.282 \%$ & $31.31 \%$ \\
\hline 6. & L.O.D. & $12.73 \%$ & $10.705 \%$ \\
\hline 7. & pH & 4.73 & 5.31 \\
\hline
\end{tabular}


1. Both the samples are free from any visible sign of contamination.

2. Moisture content and preservation time is directly proportional to LOD.

LOD of sample 1 is more than sample 2 .

3. The ash value gives the idea about inorganic matter present in any sample. This parameter is also used as standard tool for detecting impurities like silica, carbonate etc.

- Ash value - sample $1>$ sample 2

- Acid insoluble Ash - sample $1<$ sample 2

Vriddha moolak has low inorganic compounds but high acid insoluble inorganic compounds rather than Balmoolak.
4. Extractive values are useful for determination of exhausted and adulterated drugs. Water soluble extractive (W.S.E.) and Alcohol soluble extractive (A.S.E.) value are indication of the solubility of active principles of plant.

- W.S.E. - Sample $1<$ Sample 2

- A.S.E. - Sample $1>$ Sample 2

Both the sample has more water-soluble extractive value than Alcohol Soluble

Polar compounds are soluble in water so more A.S.E. value of sample 1 shows more polar compounds are present in Bal moolak and more A.S.E. value of sample 2 shows more nonpolar compounds in Vriddha moolak. 5. $\mathrm{pH}$ - Sample $1<$ Sample 2 .

Table 4: Preliminary phytochemical analysis

\begin{tabular}{|c|c|c|c|}
\hline \multirow[t]{2}{*}{ Phytochemical analysis } & \multirow[t]{2}{*}{ Experiment } & \multicolumn{2}{|c|}{ Alcoholic extract of Moolak root } \\
\hline & & Balmoolak & Vriddhmoolak \\
\hline \multirow[t]{2}{*}{ Alkaloids } & Mayer's Test & $+\mathrm{ve}$ & $+\mathrm{ve}$ \\
\hline & Dragondroff's test & $+\mathrm{ve}$ & $+\mathrm{ve}$ \\
\hline \multirow[t]{2}{*}{ Protein and Amino acid } & Ninhydrin Test & -ve & -ve \\
\hline & Millons Test (water Extract) & -ve & -ve \\
\hline Carbohydrates & Benedict Test (water Extract) & $+\mathrm{ve}$ & $+\mathrm{ve}$ \\
\hline \multirow[t]{3}{*}{ Flavonoids } & FeCl3 Test & -ve & -ve \\
\hline & Lead Acetate Test & $+\mathrm{ve}$ & $+\mathrm{ve}$ \\
\hline & Alkaline Reagent Test & -ve & -ve \\
\hline \multirow[t]{2}{*}{ Fixed oils and fats } & Spot Test & $+\mathrm{ve}$ & $+\mathrm{ve}$ \\
\hline & Saponification Test & $+\mathrm{ve}$ & $+\mathrm{ve}$ \\
\hline \multirow[t]{3}{*}{ Glycosides } & Molish Test & $+\mathrm{ve}$ & $+\mathrm{ve}$ \\
\hline & Conc. H2SO4 & -ve & -ve \\
\hline & $10 \% \mathrm{NaOH}$ & -ve & -ve \\
\hline Tannins & $\mathrm{Fecl}_{3}$ & -ve & -ve \\
\hline Terpenes \& Triterpenoids & Salkowansky Test & $+\mathrm{ve}$ & $+\mathrm{ve}$ \\
\hline Saponin test & Water extract & $+\mathrm{ve}$ & -ve \\
\hline
\end{tabular}

Saponin is present in water extract of Balmoolak which show hepatoprotective effect. Saponin is like detergent which binds as well as oil. Saponins are able to bind with bile acid and eliminate them from body, preventing cholestrol from being reabsorbed ${ }^{7}$. Saponin wash out various toxins from body. Studies has reported that saponins induced death of cancer cells and slowed tumour growth ${ }^{8}$. 


\section{Quantitative analysis}

Table 5: 1. Report for Total Phenolic content

\begin{tabular}{|c|c|c|c|}
\hline S.N. & Sample name & Type of Extract & Results \\
\hline \multirow[t]{2}{*}{1.} & \multirow{2}{*}{$\begin{array}{l}\text { Moolak (Sample I) } \\
\text { Raphanus sativus (Tender) }\end{array}$} & Water & $(1.42 \pm 0.17) \mathrm{mg} \mathrm{GAE} /$ gram of Extract \\
\hline & & Alcohol & $(0.47 \pm 0.41) \mathrm{mg} \mathrm{GAE} /$ gram of extract \\
\hline \multirow[t]{2}{*}{2.} & \multirow{2}{*}{$\begin{array}{l}\text { Moolak (Sample II) } \\
\text { Raphanus sativus (old) }\end{array}$} & Water & $(8.15 \pm 0.17) \mathrm{mg} \mathrm{GAE} /$ gram of extract \\
\hline & & Alcohol & $(2.94 \pm 0.29) \mathrm{mg} \mathrm{GAE} /$ gram of extract \\
\hline
\end{tabular}

Phenolic compounds (Both water and alcohol extracts) are more in sample 2 as compare to sample 1. Phenolic compounds grant fruits and vegetables their unique taste, flavor and health benefits. Thus, increasing the amount of phenolic compound in them enhance their quality. These compounds are critical for reproduction and growth in plants and are produced as a result of certain environmental factors such as light temperature pollution etc. They are also helpful curing damaged plants.

Table 6: 2. Report for Total Flavonoid Content

\begin{tabular}{|l|l|l|l|}
\hline S. N. & Sample name & Type of Extract & \multicolumn{1}{c|}{ Results } \\
\hline 1. & Moolak (Sample I) Raphanus sativus (Tender) & Water & $(2.64 \pm 0.10) \mathrm{mg}$ QE/Gram of extract \\
\hline 2. & Moolak (Sample II) Raphanus sativus (old) & Water & Negative \\
\hline
\end{tabular}

Flavanoids are more in sample 1 and negligible in sample 2. Qualitative test of flavonoid also showed negative result. Flavanoid compounds are detoxifying agents and stimulants for germination of spores, protective role depending on roles of micro - organism in plants. It gives odour and flovour to plant parts which may act as attractant and repellent to pollinators or pests.

\section{TLC (Thin Layer Chromatography):}

TLC of ethanol extract of Balmoolak and Vriddha moolak (Raphanus sativus Linn.) were developed in the solvent system, Toluene: Ethyl acetate (7.5: 2.5)

Figure 2: (A) TLC of Balmoolak (Left) and Vriddha moolak (Right)
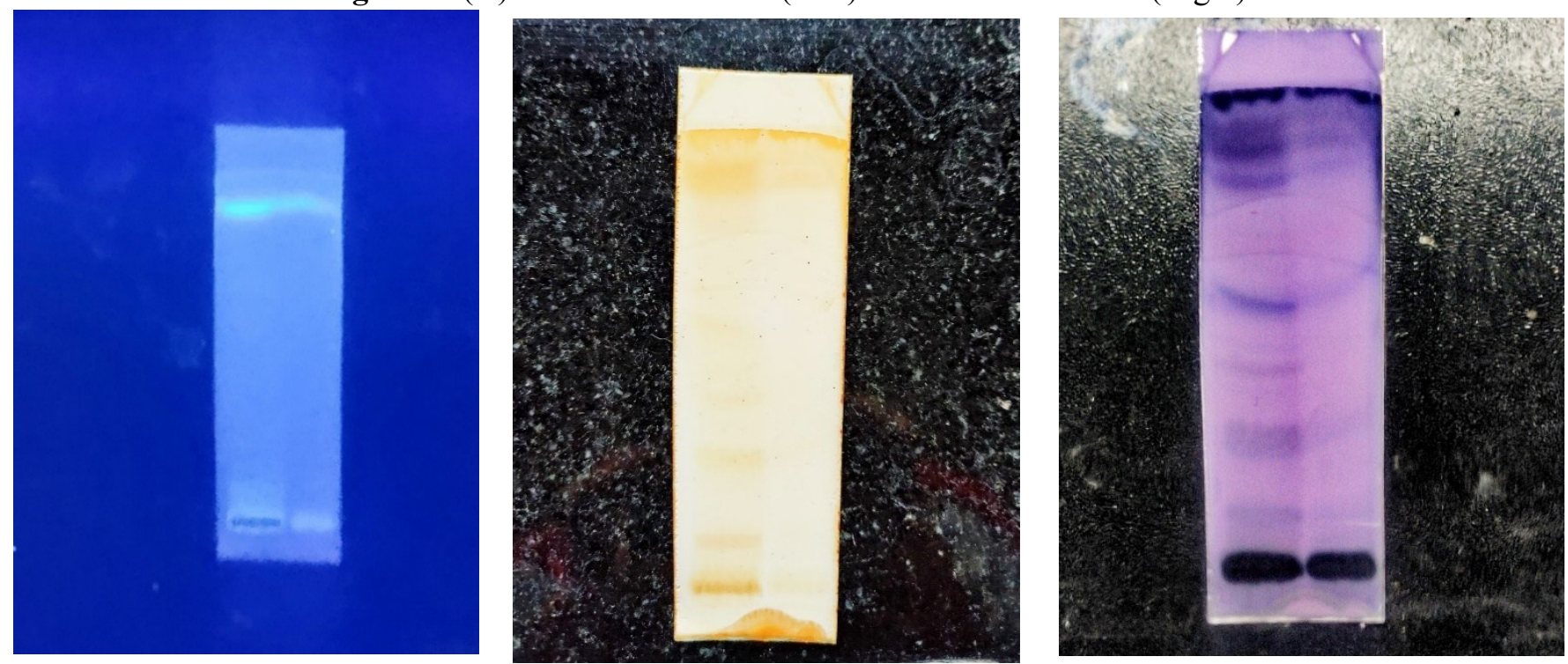

TLC under UV 366 (B) TLC after iodine treatment (C) TLC under Vaniline derivatization Detection - Under Vaninline + conc. HCl 


\section{Observation}

Bal moolak - 0.06, 0.12, 0.27, 0.42, 0.45, 0.55, 0.81, $0.87,0.92$

Vriddha moolak - 0.1, 0.12, 2.2, 0.55, 0.81, 0.8

The present study has shown different $R_{\mathrm{f}}$ values which is indicator of different compounds present in both samples.

\section{CONCLUSION}

Organoleptic studies showed that taste and smell of Balmoolak is more pungent but sweet, whereas Vriddha is less pungent and bitter. Balmoolak is used raw as salad because of its pungent taste. Macroscopic study of T.S. section of Balmoolak showed dense solid, smooth watery but Vriddha Moolak has either air filled spaces (unedible), little unenen and spongy (Edible).

Phytochemical study showed presence of saponin in water extract of Balmoolak which is absent in Vriddha moolak. Saponin wash away toxins, bind to bile acids and help to eliminate them from body, preventing cholesterol from being reabsorbed and according to previous research Raphanus sativus L. var. niger (black radish) has used, treatment of gallstones and for decreasing lipids serum. Preclinical research says people give it in traditional medicine. Total Phenolic compounds in Sample 2 are more than sample 1in both water and alcoholic extract and in water extract phenolic compound value is more than alcohol extract value in both samples. Phenolic compound and flavonoids both are secondary metabolites. Phenolic acid are non flavonoidal phenols whose synthesis increases in response to plant environmental stress. Vriddha moolak is starting stage of bolting (Bolting started due to stress) so amount of non flavonoidal phenol is greater in it. In some plants Phenolic compound are polymerized into larger molecules such as proanthocyanidins (PA: condensed tannin) and lignins which are deposited in cell wall of trachieds, vessels, fiber of xylem and phloem ${ }^{9}$. Root of Vriddha moolak becomes tough and woody and not easy to digest and absorb in GIT, Because of Lignin deposition, so Acharyas had mentioned Guru (Heavy in digestion) guna, Vistambhi (produce excessive vata and cause flatulence), Abhishyandi (which develops slipperiness and heaviness in the body and obstruct different system and cause heaviness in whole body) and Tridoshkrita. TLC Band shows nine (9) spot in Bal-moolak and six (6) spot in Vriddha-moolak after derivatization which show where three (3) spot have same $\mathrm{R}_{\mathrm{f}}$ and others have different which show different compound are present in both samples.

On the basis of phytochemical studies Balmoolak is more useful for internal use (Consumption) because of shastrokta Gunas (Properties), presence of saponin, more flavonoidal content and hepatoprotective action but mature Vriddha moolak can used for external use as kasyapa has mentioned Puran Moolak (Old radish) as Lepa for Vatajanya Shotha (Inflammation) in Khilsthana 17, Shothachikitsa Adhyaya.

\section{ACKNOWLEDGEMENT:}

I would like to thank Dr. Sunita Garg, Chief Scientist, Raw Material Herbarium and Museum Delhi (RHMD), CSIR- NISCAIR and Natural Remedies, Banglore for sharing their knowledge to drive scientific exploration. I express my genuine gratitude to Dr. N.S. Chauhan (Scientific officer Grade-II), Mr. Umakant Sahu (Scientific officer Chemistry) and Mr. Arun Parihar (Scientific officer - Pharmacognosy/Botany), State Drug Testing and Research Laboratory Raipur, Chattisgarh for provided the facility to carry out the Present study (Physico-chemical and Qualitative Phytochemical study)

I would like to thank Shri B.M. Kankanawadi Ayurveda Mahavidyalaya, Belgaum, Ayush Approved ASU Drug Testing Laboratory Lic. No. TL-8/2011 for Powder microscopy and Quantitative analysis of total Phenols and flavonoids.

\section{REFERENCES}

1. Susrut Samhita of Maharshi susruta, Edited by Kaviraj Ambikadutta Shastri, Sutrasthana chapter 46, Versus No. 313 pp 420, Chaukhambha Sanskrit Sansthan Varanasi, 2012

2. Bhavaprakash Samhita of Bhavamishra, Original text along with commentary and translation Volume 1, chapter 10, versus no. 80 - 83, Pp 372, Forward by K.C. Chunekar, Commentary by Sitaram Bulusu, Chauknambha orientalia, Varanasi, 2012. 
3. The Wealth of india, A dictionary of Indian Raw materials And Industrial Products, Vol. V, R-Z, National institute of Science Communication and Information Resources, CSIR, New Delhi, 2008. Anonymous, The Ayurvedic Pharmacopoeia of India, Part 2, Vol III, First Edition, 146, 147,198.

4. Pouteau Sylvie, Albertini Catherine, The significance of bolting and floral transitions as indicators of reproductive phase change in Arabidopsis, Journal of Experimental Botany, Volume 60, Issue 12, August 2009, Pp 3367-3377

5. Anonymous, The Ayurvedic Pharmacopoeia of India, Part-2, Vol-III, First Edition, 146, 147,198.

6. Chase \& Pratt 1949 with some modification - From the manual quality control of herbal drugs (NBRI).

7. Mishra Nidhi, Rajput Prakash Singh, Mishra Rajesh Chandra, Phytochemical uses of saponin containing herbs, International Journal of Chemistry Studies, ISSN; 2581 -348 X, Volume 1; Issue 2; November 2017; Page No. 12 - 16

8. Yan 11, Zhang YJ, Gao WY, Man SL, Wang Y. In vitro and in vivo anticancer activity of steroid saponin of Paris polyphylla var. yunnanensis, Exp. Oncol 2009, 31(1):27-32.

9. Ali Ghasemzaden and Neda Ghasemzaden, Flavonoids and phenolic acids: Role and biochemical activity in plants and human, Journal of Medicinal Plants Research Vol. 5(31), pp. 6697 - 6703, 23 december, ISSN 1996087, 2011 Academic journals.

\section{Source of Support: Nil}

\section{Conflict of Interest: None Declared}

How to cite this URL: Rajani Patel et al: Pharmacognostical And Phytochemical Research Study Of Root Part Of Bal (Tender) And Vriddha (Bolt) Moolak (Raphanus Sativus Linn.). International Ayurvedic Medical Journal \{online\} 2021 \{cited May, 2021\} Available from: http://www.iamj.in/posts/images/upload/2888 2895.pdf 